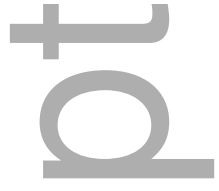

rnatives to reduce the

${ }^{2}$, Uglem I $^{4}$

¿. P.O. Box 99, 03080,

School of BioSciences,

Memorial University of

Norway

t ecological and genetic ten attempted. Here, we ith escaped fish size, the rs varied among species,

Recapture success was $\mathrm{d}$, regardless of species. rous tracking studies of cape incident for highest $\mathrm{n}$ recapture efforts rarely

This is the author manuscript accepted for publication and has undergone full peer review but has not been through the copyediting, typesetting, pagination and proofreading process, which may lead to differences between this version and the Version of Record. Please cite this article as doi: $10.1111 /$ raq.12153

This article is protected by copyright. All rights reserved 
larine habitats, with rare se-scale recapture efforts tively. We suggest three llations of predatory fish :t impact offset programs ısure technical standards capes.

wherever fish are farmed \& Joyce 2005, Morris et Blanchfield 2013, Serra77-2009, some 9 million t al. 2015). As escapees ing grounds, a range of ie transfer from escapees trogression from farmed zd survival and lifetime lations (McGinnity et al. Ig of wild fish (Lura \& 4, 2006).

ative in nature, through 1 the implementation of escape (Damsgård et al. its of escapees once they ed with wild fish (Fraser from the environment. is (Supplementary Table local fisheries operators. JW recapture must occur, stipulates the amount of

This article is protected by copyright. All rights reserved 
I. No synthesis exists of

ว make evidence-based

e and recapture studies

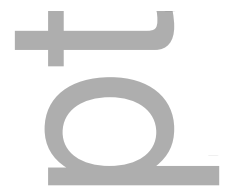

with species farmed and tive to when the escape Id how escapes enter the y to succeed. Two recent to hundreds of thousands z events from September in Norway revealed that , trout and Atlantic cod $f$ the number of escaped 1 failures of entire cages :timated to have escaped ng mass escape incidents 1. 2015). These analyses stimate the true level of ither not detected and/or er, less detectable escape true number of escapees, : point of escape, as this )lan.

scaped from aquaculture and a meta-analysis of : likelihood of recapture ake recommendations to regulators to: 1) improve cceed; and alternately, 2) successful, while negative lents that may reduce the re of escapees that require

This article is protected by copyright. All rights reserved 
icholar with the following Iture*) AND (escape* OR $\mathrm{n}$ the field. Results were one as they were from an led after accessing the full

on recapture success rates the location and recapture ıcidents from marine searoperly estimate recapture as their main objective is at for extended periods to such cases, each release fic event once recaptured. ocation, country, region, apture success rates and it through correspondence lues to mean length using Ir variables were $\log (\mathrm{x}+1)$ : regression or ANOVA. els constructed using the ww.R-project.org/).

1ese papers described 123 in the meta-analysis.

scapees remain around the 1d the position of the farm ave documented that fish

This article is protected by copyright. All rights reserved 

ecapture at the escape site e potential for successful et al. 2011). Post-escape ıstic telemetry (Skilbrei et J12). This has assisted in ensen 2010, Chittenden et spez et al. 2012), while in $d$ the reach of traditional 'hittenden et al. 2011).

l-cage aquaculture occurs. Skilbrei et al. 2006; Green sund in landings of many tured by local fisheries in ; Arechavala-Lopez et al. gears have been used to pelagic trawlers and longg are common techniques

reefs and spear fishing to es that usually aggregate ; Santos et al. 2006; Grati limited. However, several that released fish moved at beach-seines or beachić \& Dulčić 1997; Bayle-

recapturing escapees (e.g. some kind of herding or rapped. Examples of such 
in traditional commercial unharmed, which may be Norwegian fjords; SerraI salmon, but with varying I.

$\mathrm{h}$ in Norway (Furevik \& re been tested for live reifferent sizes and designs, ent entrances (Figure 2c). t the target fish. Similarly, zes either in the bottom or 2013) have been tested to tpees. Floating traps were tract and capture the wild 10). Similarly, a standard ; been tested to recapture I were captured (Sanchez-

been designed to capture he fisheries context in the ie certain methodologies tre used, as they allow for

: that is representative of uropean waters (Figure 1), $\mathrm{n}=123$ ), with limited od: $8 \pm 10 \%, \mathrm{n}=46$; sea $\downarrow$ recapture rates are linked ffort. In general, reported th fish size (Table 3). This apees compared to large

This article is protected by copyright. All rights reserved 
). Highest recapture rates rgensen 2010), and $69 \%$ eleases of $<100$ large fish vere significantly lower in k et al. 1990; McKinell \& udies where $>10000$ fish success after large scale duals may result from the due to limited adaptation the release site, as large sster et al. 2009). Further, during storms, when most 1 et al. 2015) for logistical : escape event, rather than fter storms; and 2) better captures, when just a few ss (e.g. Uglem et al. 2008,

kilbrei (2010a) reported a gill-netting and angling ensen 2010), with coastal traps and pelagic trawling assessed recapture rates of low recapture rates by 1998; Jutila et al. 2003). although Skilbrei (2012) 
mall scale releases/escape large numbers of smaller ıcidents from commercial 312 escapees in Finnmark, ;aland, Norway (recapture ia, Canada (recapture rate n occasion it may be high: 4.

rd systems in Norway and zod tagged with acoustic shile Zimmermann et al. ımercial fisheries during a ilarly, Serra-Llinares et al. is of thousands of juvenile ional 0.1-4.5\% recapture. m cod (Kristiansen 1999; $0.1-8.6 \%)$.

;almon: simulated escapes ly higher recapture rates : higher mortality rates of Ires et al. 2013), although od at liberty (> 5 months;

sea bass (Table 1), which ; to be made where these Idy carried out on escaped 

ies of hatchery-reared sea ds, Strait of Gibraltar and Although no studies exist iplodus sargus), which is ates $(0.4-6.7 \%)$ by local

1200 fish in the Western y professional fishermen ıpture rate after simulated zational and professional ¿ Canary Islands (Atlantic sea cages resulted in $20 \%$ ledo-Guedes et al. 2013). who intensively fished the ata is more limited for sea ilar; recapture rates were size (Figures 2, 3).

sstimates of real escape

ad recapture success draw that escape from sea-cage ved $<100$ fish, with some and individuals. A central ehaviours and dispersal of . 2011, Arechavala-Lopez , detailed and informative small or so-called 'leaky' es, when most fish escape . Most large scale escape ; structures fail, compared reasons. How the chaotic

This article is protected by copyright. All rights reserved 

I recapture success of fish isdictional prohibitions on

are undertaken and where ted salmon escapes have sas the bulk of production on predominantly swim in $\mathrm{s}$ fish are less bound by losed fjord environments, rapid and widespread, and tt present, there is limited

ags that enable company-, 000; stable-isotope otolith 2015c). For the first time, escape from mass escape 1 escape characteristics.

lividuals post-escape, will the possibility to mix and ear the point of escape, in le a broad range of papers wild in the long-term (e.g. ge remains concerning the term following an escape

ape, is substantial.

This article is protected by copyright. All rights reserved 
Im tags retrieved from the st $1 \%$ of recaptures came ale aggregations of saithe 2009), initial predation of 1ares et al. (2013). High Justic tags occurred in the release farm (Arechavalaaround sea bream and sea )8; Fernandez-Jover et al.

I management mechanism ig the "wall of predatory redators can provide the ; capture 10 to 100 times deployed in the vicinity of al predation by removing

jes, such as reducing the fish to reduce the benthic ste feed and thus reducing ning predator populations poor recapture rates with , reducing the success of $\geq$ critical to reducing their $\mathrm{g}$ and dispersing as if they vers, where they may be

where escapees can be

mandatory mechanism by tal damage by paying for sould be location-specific

This article is protected by copyright. All rights reserved 
z compensation generated $s$ of greatest conservation nsatory mechanisms have have proved effective for

environmental offsetting waters than in the marine sawning season. A total of Statistics Norway, 2013). ad 72000 escaped salmon ned salmon were reported 1 underestimate given the reported escapees were mately $50 \%$ of salmon in ?-3 times higher than that zaped salmon enter rivers. breeding between farmed nservatively, equivalent to

rivers to remove farmed 1 river barrier traps. The se as high as in the regular bility of fishers to visually wild fish can be released awning rivers exist, but a ed and wild from visual fish during capture and ty similar to that resulting cumented success rates of e management option in success in separating wild ıented to visually identify

This article is protected by copyright. All rights reserved 
sarly identifiable and have ses of tens of thousands of here this species does not )13). Directed removal of e occur with near $100 \%$ es are invasive and clearly Id.

ction in Norway, revealed $\mathrm{g}$ and operation of for sean declined from $>600000$ ser of salmon held in seasuccess of this measure to ould introduce a technical ns to enforce the standard. have legislated technical ith sufficient strength to neasures elsewhere would

ms in marine habitats and ing fish after escape, at or $r$, the weight of evidence : efforts are often delayed lese two factors mean that ms have been successful. only in specific instances fish escape restricting the 

ie wild through promoting ure activities into habitats :chnologies that minimize sures. All three have the appropriate.

Jerez P (2011) Immediate editerranean Sea. J Appl

erez P (2012) Post-escape fisheries in the Western

2013) Reared fish, farmed Mediterranean aquaculture

114) Simulating escapes of shermen. J Appl Ichthyol

xcent to fish farm cages.

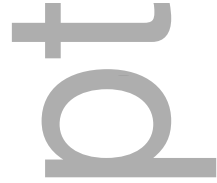

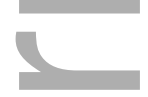
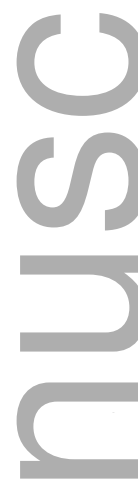

\author{
fisheries in the Western
}
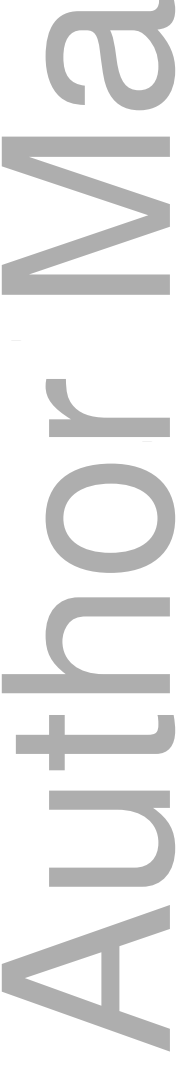

ar J, McKinley SR (2011) I Interact 1:215-224 498 
12) Net-biting and escape st traits. Aquacult Environ

(2014) Osmotic induction J Mar Sci 71:2530-2538

le C (2002) Attraction of and short-term variability.

from sea-cage aquaculture onograph $\quad 32: \quad 55-60$

Jilsen R, Bjørn PA (2009) 'osystem effect. Mar Ecol

al. (2011) Proxy measures ¡ical traps for wild gadoid 07) Possible influence of essolonghi lagoon (Ionian 08) Seasonal patterns and ¿ES J Mar Sci 65: 1153- 
he reproductive behaviour

00) Lifetime success and 1517-1523

; of triploid fish. Fish Sci

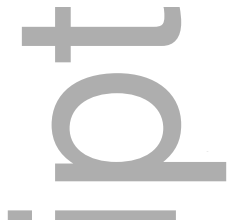

vtail kingfish via natural 'pulation genetic structure

netic analysis of stomach tlantic salmon originating

pulation genetic structure
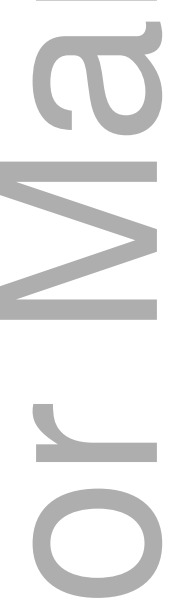

lar L.) released from two

'mo salar, from simulated

562

563

564

565

566

567

568

\author{
ects of salmon farming on \\ 17 \\ ageorgiou N, Karakassis \\ cape events from sea cage
}

This article is protected by copyright. All rights reserved 
hes from Norwegian sea1:71-83

mon (Salmo salar). Can J

ir ecology and interaction

1 farmed female Atlantic

almon (Salmo salar) and 172

er D, O'Hea B, Cooke D, $\mathrm{n}$ of wild populations of non. Proc R Soc Lond B ings JA (2008) Prevalence h American rivers. Can J sapture rates of North-east iish Biology 54: 213-217

on Salmo salar following 74

ial freshwater aquaculture

This article is protected by copyright. All rights reserved 
le C (2013) Post-escape $s$ and their potential for

Idance of escaped farmed

1' farmed Atlantic salmon si 66:278-288

simulated escaped farmed !06-1215

st-smolts from a simulated -scale escape experiment. -season smolts of farmed he annual numbers and in Norway. ICES J Mar differences between wild lile: facing ecological and 
in C\&R story. In: Global

) Detecting the degree of 'ntrarchus labrax escapes 23:203-212

saped introduced sea bass raturity in coastal habitats

laculture escape event on

Havbruk 2007:11-12 (in 656

iotemporal distribution of 58-170

astal and oceanic Atlantic t 1:11-19

and survival of sonically ar Sci 63:1218-1223

4) Stable isotope marking viron Interact 5:143-154

rsion during egg swelling quat Sci 72: 722-727

lustry-scale mass marking

This article is protected by copyright. All rights reserved 
rries bycatch-biodiversity

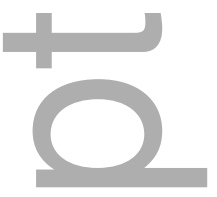

f net cage biting and the ling and cage enrichment.

wild and escapee farmed

\begin{tabular}{ccccccc}
\hline Species & Location / & Average & Number of fish & Recapture & Capture & Reference \\
& Country & fish size & escaped & success & methodology & \\
& $(\mathrm{cm})$ & & $(\%)$ & & \\
& & & & \\
\hline
\end{tabular}

D. labrax

Western

Mediterranean

Sea / Spain
26

1186

\subsection{Anglers/}

fishing rods

(2) ed farmed fish (either real tic salmon, (Salmo salar), (Sparus aurata) and sea ipture rate $(\%)$ and fishing ies; (3) Unknown fishing

$\begin{array}{cccccl}\text { G. morhua } & \begin{array}{c}\text { North Atlantic } \\ \text { fjord system/ }\end{array} & 27 & 1000 & 5.4 & \begin{array}{l}\text { Local } \\ \text { fishermen (3) }\end{array}\end{array}$

This article is protected by copyright. All rights reserved 
Norway

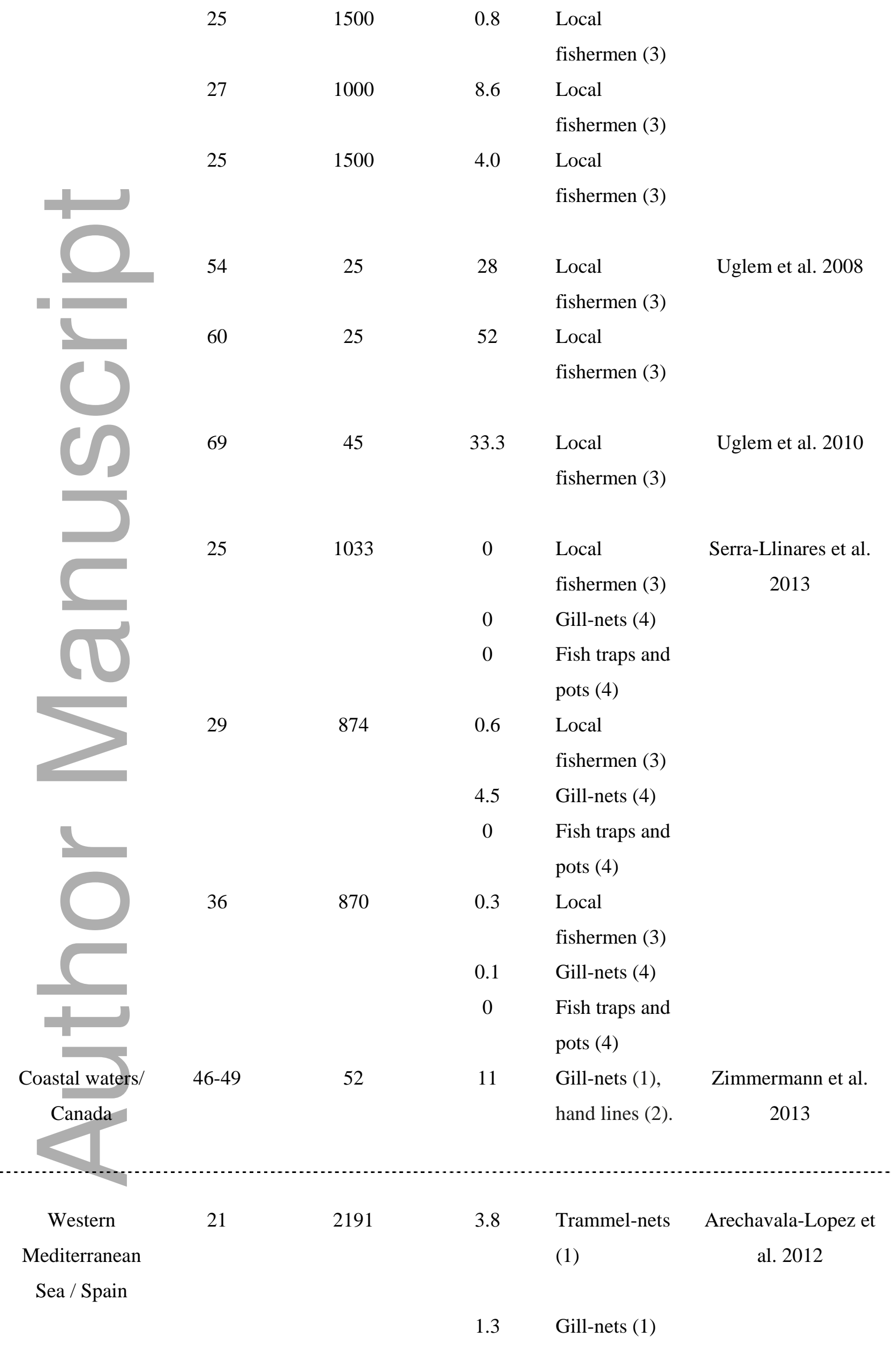


$1.1 \quad$ Anglers/

Fishing rods

(2)

$1.1 \quad$ Spear-fishing

(2)

S. salar

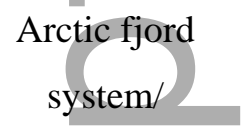

Norway

(

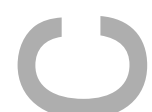

Baltic Sea /

Sweden

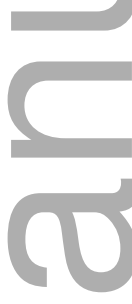

North Atlantic

fjord system/

Norway

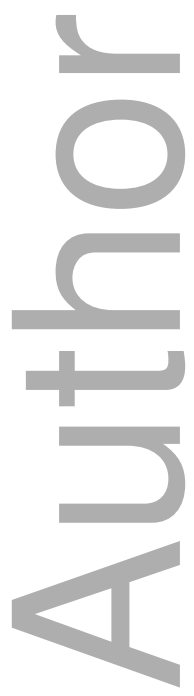

86

39

$\begin{array}{ll}15-16 & \sim 15000 \\ 14-15 & \sim 13500 \\ 14-16 & \sim 15000\end{array}$

60

1012

5.5 Gill-nets (4)

$\sim 10 \quad$ Professional

fisheries (3)

McKinell \&

$\sim$ Professional

fisheries (3)

1.5 Professional

fisheries (3)

1.3 Gill-nets (1)

$0 \quad$ Fish traps (4)

73

1996

4.6 Local

fishermen

$(1,2)$

72

2499

4.6 Local

fishermen

$(1,2)$

24

3700

2000

Lundqvist 2000

Furevik et al. 1990

Hansen 2006

Anglers/

Skilbrei 2010a

Fishing rods

(2)

$0 \quad$ Gill-nets (1)

26

$0 \quad$ Anglers/
Chittenden et al. 2011 
Fishing rods

(2)

\begin{tabular}{|c|c|c|c|c|}
\hline & & 0.2 & Gill-nets (1) & \\
\hline \multirow[t]{4}{*}{33} & 2000 & 12.3 & Anglers/ & \\
\hline & & & Fishing rods & \\
\hline & & & (2) & \\
\hline & & 2.2 & Gill-nets (1) & \\
\hline \multirow[t]{4}{*}{40} & 2000 & 12.7 & Anglers/ & \\
\hline & & & Fishing rods & \\
\hline & & & (2) & \\
\hline & & 22.4 & Gill-nets (1) & \\
\hline \multirow[t]{4}{*}{45} & 1780 & 2.9 & Anglers/ & \\
\hline & & & Fishing rods & \\
\hline & & & (2) & \\
\hline & & 26.2 & Gill-nets (1) & \\
\hline \multirow[t]{4}{*}{17} & 1936 & 0.3 & Local & Skilbrei 2010b \\
\hline & & & fishermen (3) & \\
\hline & 2002 & 0.9 & Local & \\
\hline & & & fishermen (3) & \\
\hline \multirow[t]{4}{*}{18} & 1978 & 0.9 & Local & \\
\hline & & & fishermen (3) & \\
\hline & 2000 & 0.9 & Local & \\
\hline & & & fishermen (3) & \\
\hline \multirow[t]{4}{*}{21} & 2000 & 1.0 & Local & \\
\hline & & & fishermen (3) & \\
\hline & 1999 & 0.8 & Local & \\
\hline & & & fishermen (3) & \\
\hline 64 & 19 & 15.8 & Local & Skilbrei et al. 2010 \\
\hline & & & fishermen (3) & \\
\hline \multirow[t]{2}{*}{72} & 24 & 62.5 & Local & \\
\hline & & & fishermen (3) & \\
\hline \multirow[t]{2}{*}{54} & 29 & 37.9 & Local & \\
\hline & & & fishermen (3) & \\
\hline \multirow[t]{2}{*}{61} & 30 & 50 & Local & \\
\hline & & & fishermen (3) & \\
\hline \multirow[t]{2}{*}{70} & 30 & 20 & Local & \\
\hline & & & fishermen (3) & \\
\hline
\end{tabular}




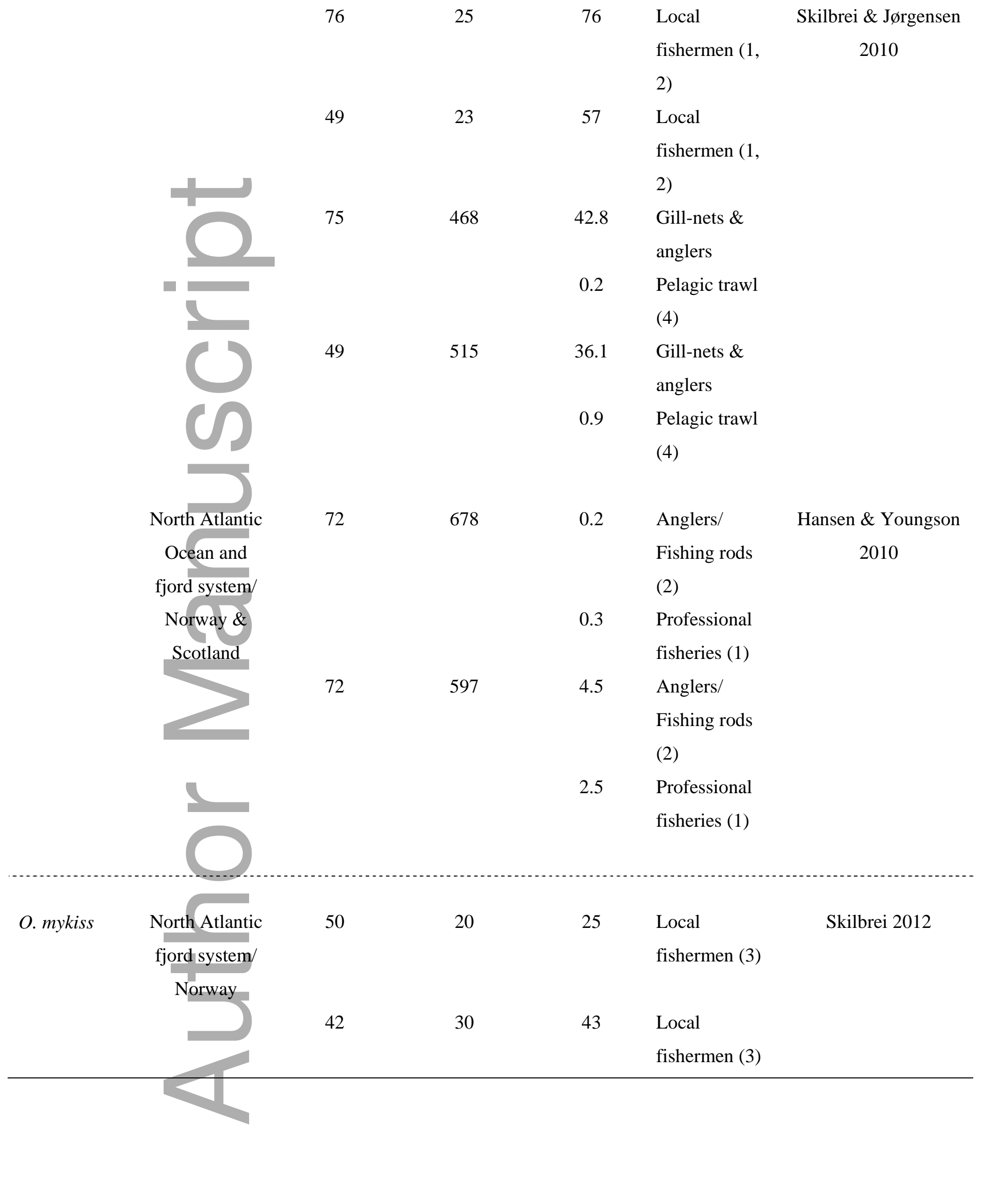

This article is protected by copyright. All rights reserved 


\begin{tabular}{|c|c|c|c|c|c|c|}
\hline \multirow[t]{2}{*}{ Species } & \multicolumn{3}{|c|}{ Fish size: means $( \pm S D)$ or ranges } & \multicolumn{2}{|c|}{ Dispersal from farms } & \multirow[t]{2}{*}{ References } \\
\hline & $\begin{array}{l}\text { No. fish } \\
\text { released }\end{array}$ & $\mathrm{SL}(\mathrm{cm})$ & W (kg) & $\begin{array}{c}\text { First move } \\
\text { away (hours) }\end{array}$ & $\begin{array}{c}\sim 50 \% \\
\text { dispersed }\end{array}$ & \\
\hline \multirow{10}{*}{$\begin{array}{l}\text { Atlantic } \\
\text { salmon } \\
\text { (S. salar) }\end{array}$} & $9-10$ & $86 \pm 5$ & $7.4 \pm 1.4$ & $<24$ & $48-96$ & Chittenden et al. 2011 \\
\hline & $19-30$ & $51-78$ & $2.3-5.1$ & $<24$ & $<48$ & Skilbrei et al. 2010 \\
\hline & $9-20$ & $20-30$ & $0.07-0.25$ & $<24$ & $<24$ & Skilbrei 2013 \\
\hline & $15-20$ & $20-54$ & $0.09-2.3$ & $<24$ & $<24$ & Skilbrei 2010 \\
\hline & & $45-81$ & $1.2-6.0$ & $<24$ & $<24$ & Skilbrei \& Jørgensen 2010 \\
\hline & 37 & 54 & 1.4 & $<24$ & $<24$ & Solem et al. 2012 \\
\hline & 50 & $188 \pm 12$ & $71 \pm 14$ & $<24$ & $48-72$ * & Uglem et al. 2013 \\
\hline & & $189 \pm 7$ & $66 \pm 8$ & $<24$ & $<24^{\star}$ & Uglem et al. 2013 \\
\hline & & $40-58$ & - & $<12$ & $<24$ & Whoriskey et al. 2006 \\
\hline & & $60 \pm 6$ & $2.6 \pm 0.8$ & $0-6$ & $0-6$ & Furevik et al. 1990 \\
\hline \multirow{5}{*}{$\begin{array}{l}\text { Rainbow trout } \\
\text { (O. mykiss) }\end{array}$} & 20 & $40-56$ & $0.8-3.7$ & $<24$ & $48-120$ & Skilbrei 2012 \\
\hline & & - & 0.8 & $<24$ & $24-48$ & Blanchfield et al. 2009 \\
\hline & $66-68$ & - & $1.5-2.0$ & $<24$ & $96-816$ * & Bridger et al. 2001 \\
\hline & $10-30$ & $35-44$ & $0.8-1.5$ & $<24$ & $24-168^{*}$ & Patterson \& Blanchfield 2013 \\
\hline & 48 & $48-58$ & $\sim 2$ & $<24$ & $<72^{*}$ & Lindberg et al. 2009 \\
\hline \multirow{3}{*}{$\begin{array}{l}\text { Atlantic cod } \\
\text { (G. moruha) }\end{array}$} & $14-21$ & $44-50$ & - & $2-3$ & $5-19$ & Zimmerman et al. 2013 \\
\hline & & $31 \pm 2$ & $0.4 \pm 0.1$ & $<24$ & $48-72$ & Serra-Llinares et al. 2013 \\
\hline & & $47-66$ & - & $<24$ & $<24$ & Uglem et al. 2008 \\
\hline $\begin{array}{l}\text { Sea bream } \\
\text { (S. aurata) }\end{array}$ & & $26-29$ & $0.4-0.6$ & $<24$ & $96-120^{*}$ & Arechavala-Lopez et al. 2012 \\
\hline $\begin{array}{l}\text { Sea bass } \\
(D . \text { labrax })\end{array}$ & 10 & $28 \pm 1$ & $0.4 \pm 0.04$ & $<24$ & $120^{*}$ & Arechavala-Lopez et al. 2011 \\
\hline $\begin{array}{l}\text { Meagre } \\
\text { (A. regius) }\end{array}$ & & $33-49$ & - & $<12$ & 48 & Arechavala-Lopez et al. $2015 \mathrm{a}$ \\
\hline
\end{tabular}




\begin{tabular}{|c|c|c|c|c|c|c|c|}
\hline Model $(y \sim x)$ & Test & df & Direction & Test stat & $\mathrm{R}^{2}$ & $\mathrm{p}$ & \\
\hline \multicolumn{8}{|c|}{ Number released } \\
\hline \multicolumn{8}{|l|}{ mean size } \\
\hline All species & Linear regression & 120 & - & $t=55.7$ & 0.31 & $<0.0001$ & $* * *$ \\
\hline S. salar & Linear regression & 62 & - & $t=106.2$ & 0.63 & $<0.0001$ & *** \\
\hline G. morhua & Linear regression & 62 & - & $t=53.2$ & 0.54 & $<0.0001$ & $* * *$ \\
\hline \multirow{2}{*}{\multicolumn{8}{|c|}{$\begin{array}{l}\text { Recapture success } \\
\text { rate } \sim \text { mean size }\end{array}$}} \\
\hline & & & & & & & \\
\hline All species & Beta regression & 120 & + & $z=3.06$ & 0.04 & 0.002 & $* * *$ \\
\hline S. salar & Beta regression & 61 & + & $z=2.60$ & 0.11 & 0.009 & $* * *$ \\
\hline G. morhua & Beta regression & 43 & + & $z=5.55$ & 0.16 & $<0.0001$ & $* * *$ \\
\hline
\end{tabular}

\section{Recapture success}

rate environment

(exposed or fjord)

S. salar

Beta regression

$61+$ fjord

$z=1.66$

0.06

0.098
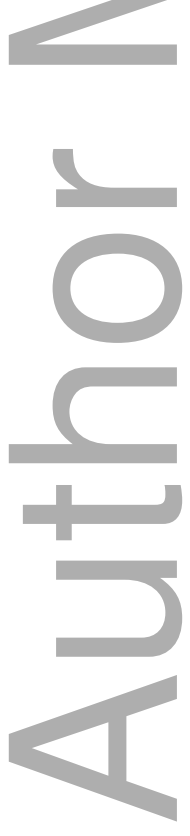

fish released, grouped by

grouped by species. Four 1 $5.5 \%$ recaptured; 50181 with $15.1 \%)$. Linear lines aped, grouped by species.

This article is protected by copyright. All rights reserved 


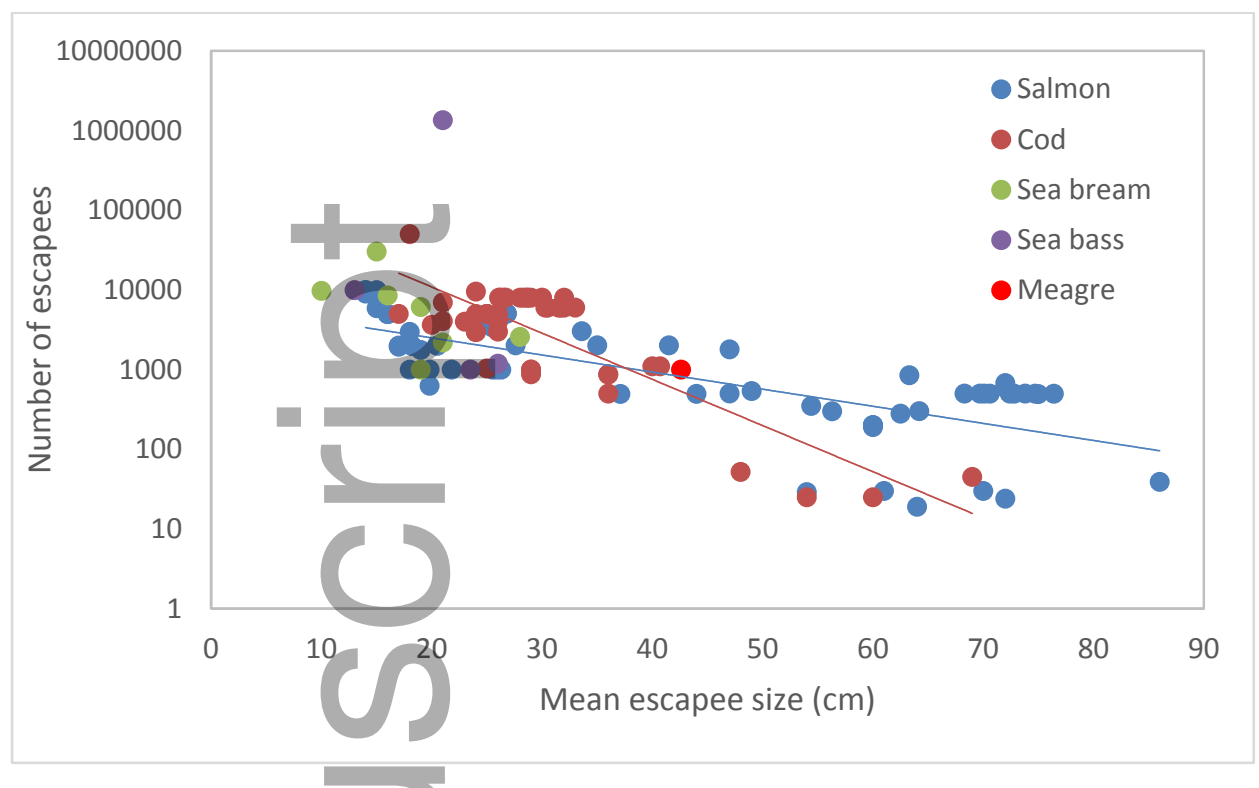

745

746

747

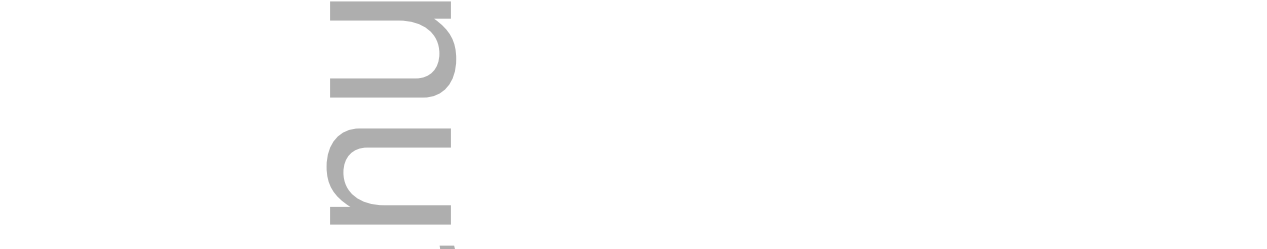

751
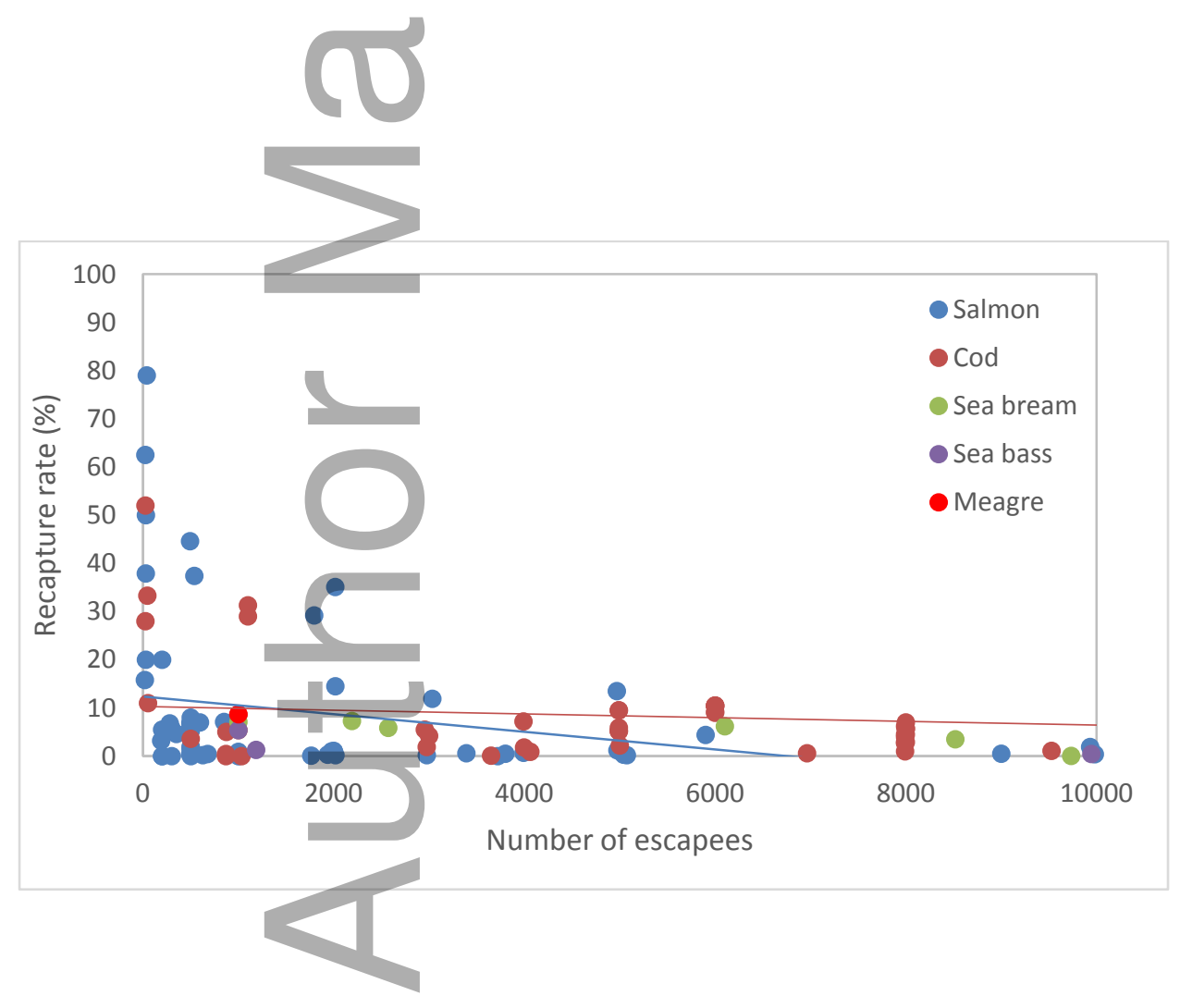

752

753

This article is protected by copyright. All rights reserved 


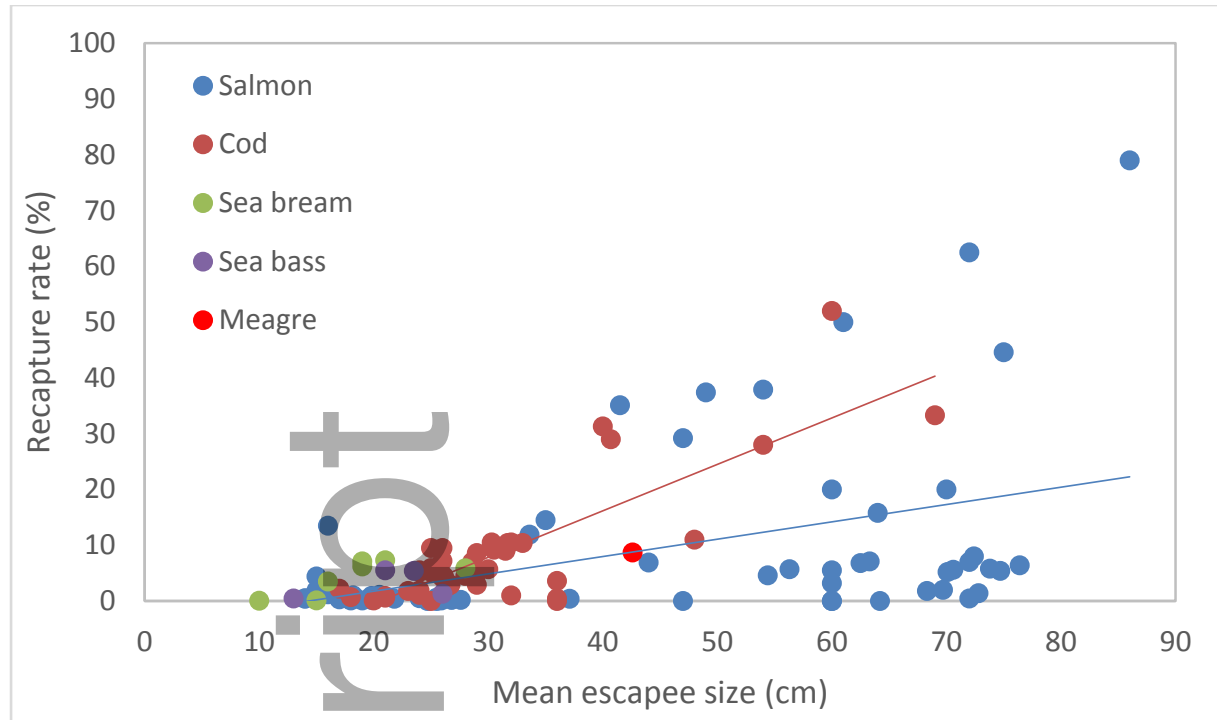

754

755

756

757

758

759

760

761

762

763

arm after an escape event any person other than the ig around a fish farm. The 'es may occur even during r regulated by the local ich escaped fish may be

vho recaptures or attempts writing the results of the or attempted recapture". 
propriate, may assist with ıer and local wild fishery or the use of gill nets to

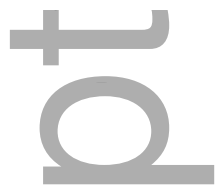

$$
\text { Jr the use of gill nets to }
$$

ent of escapes, as regional Plan for development of tifies the prevention and ween 2016-2018 (July urage the development of

ensure actions to mitigate sed a Regional Plan for contingency plan against apes in extreme weather isherman or other fishing and Murcia, have regional it preventative measures, t populations and fisheries IWw.planacuicultura.es). $\underline{\text { Ira/docs/pesca/proac/Doc }}$

เrine finfish aquaculturean escape event. Farmers :scapes may be recaptured 

litiated in response to the are required to implement Failure to implement the nvalidation of the marine

to B.C. Reg. 207/2011, is must be in place for all 1 duties. Time-frames are ly states that 'the licence bia and local government ist stock, and (b) will not

$\underline{\text { section3 }}$

ws fish farmers to fish for Id Oceans, Government of re boat to fish within one ve a live brailing ability caught incidentally. The ssued for the recapture of r to obtain, and fish under, had applied for this ZZA 

ngency plan (D.S. 320/01 sated for 5 days after the zeding at the normal time. tigation program has been

ices.pdf

while fish may remain in Iain for extended periods. cial exemption granted by only allows fishing where tock due to size or colour $\mathrm{s}$ are limited to acceptable med fish are defined as a 


\section{University Library}

\section{- M M I N E R VA \\ A gateway to Melbourne's research publications}

Minerva Access is the Institutional Repository of The University of Melbourne

Author/s:

Dempster, T;Arechavala-Lopez, P;Barrett, LT;Fleming, IA;Sanchez-Jerez, P;Uglem, I

Title:

Recapturing escaped fish from marine aquaculture is largely unsuccessful: alternatives to reduce the number of escapees in the wild

Date:

2018-03-01

\section{Citation:}

Dempster, T., Arechavala-Lopez, P., Barrett, L. T., Fleming, I. A., Sanchez-Jerez, P. \& Uglem, I. (2018). Recapturing escaped fish from marine aquaculture is largely unsuccessful: alternatives to reduce the number of escapees in the wild. Reviews in Aquaculture, 10 (1), pp.153-167. https://doi.org/10.1111/raq. 12153.

Persistent Link:

http://hdl.handle.net/11343/291395 